\begin{tabular}{cc|c}
\hline Tar. Bil. Der. & $\begin{array}{c}\text { Tarım Bilimleri Dergisi } \\
\text { Dergi web sayfası: }\end{array}$ & Journal of Agricultural Sciences \\
& $\begin{array}{c}\text { Jww.agri.ankara.edu.tr/dergi } \\
\text { www.agri.ankara.edu.tr/journal }\end{array}$ & wwomepage: \\
\hline
\end{tabular}

\title{
Vegetative Compatibility Groups and Pathogenicity of Verticillium dahliae Isolates from Potato Plants in Erzurum Province
}

\author{
Elif DANE ${ }^{\mathrm{a}}, \quad$ Erkol DEMIRCi $\dot{\mathrm{b}}^{\mathrm{b}}$ \\ ${ }^{a}$ Variety Registration and Seed Certification Center, Ministry of Food Agriculture and Livestock, Ankara, TURKEY \\ ${ }^{b}$ Maçka Vocational School, Karadeniz Technical University, Trabzon, TURKEY
}

\section{ARTICLE INFO}

Research Article-Crop Production～DOI: 10.1501/Tarimbil_0000001198

Corresponding author: Erkol DEMIRCİ, e-mail: drerkol@ hotmail.com, Tel: +90 (462) 3777632

Received: 31 March 2012, Received in revised form: 28 August 2012, Accepted: 18 December 2012

\section{ABSTRACT}

One hundred eleven isolates of Verticillium dahliae were obtained from potato plants in Erzurum province, Turkey. The pathogen was isolated from $7.6 \%$ of the stems collected. All isolates were assigned to vegetative compatibility groups (VCGs) using nitrate-nonutilizing (nit) mutants. In total, 240 nit mutants were obtained from $V$. dahliae isolates, and classified as nit $1(71 \%)$ and nitM (29\%). Two VCGs were found and identified as VCG 2B (34 isolates) and VCG 4B (77 isolates) by using tester isolates of known VCGs. Pathogenicity of $V$. dahliae isolates was tested on potato (cv. Marfona) by the root-dip method. Both VCG 2B and VCG 4B isolates showed similar aggressiveness on potato. This is the first study of VCGs of $V$. dahliae isolates from potato plants in Turkey.

Key words: Potato; Verticillium dahliae; Nit mutants; Vegetative compatibility groups; Pathogenicity

\section{Erzurum İlinde Patates Bitkilerinden Elde Edilen Verticillium dahliae İzolatlarının Vejetatif Uyum Grupları ve Patojeniteleri}

\section{ESER BILGISI}

Araştırma Makalesi - Bitkisel Üretim

Sorumlu Yazar: Erkol DEMİRCi,, e-posta: drerkol@ hotmail.com, Tel: +90 (462) 3777632

Geliş tarihi: 31 Mart 2012, Düzeltmelerin gelişi: 28 Ağustos 2012, Kabul: 18 Aralık 2012

\section{ÖZET}

Erzurum ilinde patates bitkilerinden 111 Verticillium dahliae izolatı elde edilmiştir. Toplanan gövdelerin \% 7.6'sından patojen izole edilmiştir. Nitrat kullanamayan (nit) mutantlar kullanılarak tüm izolatların vejetatif uyum grupları (VCG) belirlenmiştir. V. dahliae izolatlarından toplamda 240 nit mutant elde edilmiş olup, bunların \% 71'i nit1 ve \% 29'u nitM olarak sinıflandırılmıştır. Bilinen test izolatları kullanılarak VCG 2B (34 izolat) ve VCG 4B (77 izolat) olmak üzere iki VCG'u belirlenmiştir. Kök daldırma metodu kullanılarak $V$. dahliae izolatlarının patojenitesi Marfona patates çeşidinde test edilmiştir. VCG 2B ve VCG 4B'ye ait izolatlar patateste benzer saldırganlık göstermiştir. Türkiye'de patates bitkilerinden elde edilen $V$. dahliae izolatlarının VCG'larının belirlendiği ilk çalışmadır.

Anahtar Kelimeler: Patates; Verticillium dahliae; Nit mutantlar; Vejetatif uyum grupları; Patojenite

() Ankara Üniversitesi Ziraat Fakültesi

\section{Introduction}

Verticillium dahliae Kleb. is a soilborne plant pathogen responsible for severe damage on many crop species including potato (Pegg \& Brady 2002). Potato is an important crop in Erzurum province, where more than 3,000 ha of potatoes are planted. Verticillium wilt on potato caused by $V$. dahliae has been a serious problem in this area recently. On potato, this fungus causes early senescence of plants and a light brown discoloration in 
the vascular ring of tubers (Rich 1986), and it can cause a reduction of both yield and quality. Many weed species also have been reported as hosts of $V$. dahliae (Pegg \& Brady 2002; Ligoxigakis et al 2002). The pathogen has been isolated from five weed species in potato fields in Erzurum (Demirci \& Genc 2009).

The identification of vegetative compatibility groups (VCGs) has proved to be a powerful tool in determining the fungal genetic structure of $V$. dahliae, an anamorphic fungus with no known sexual stage. By using nitrate-nonutilizing (nit) mutants, four major VCGs (VCG 1, VCG 2, VCG 3 and VCG 4) of $V$. dahliae have been reported. VCG 2 and 4 have been further divided into subgroups ( $2 \mathrm{~A}$ and $2 \mathrm{~B}, 4 \mathrm{~A}$ and $4 \mathrm{~B}$, respectively) based on differential interactions between isolates (Joaquim \& Rowe 1990\&1991). VCGs 2, 2A, 2B, 4A, 4B and/or 4A/B have been detected among $V$. dahliae isolates from potato plants (Joaquim \& Rowe 1991; Strausbaugh 1993; Korolev et al 2000; Tsror et al 2001; Zeise \& Tiedemann Von 2002).

The aim of this research was to determine the VCGs of $V$. dahliae isolates from potato plants in Erzurum, Turkey and to investigate the pathogenicity of these isolates on potato.

\section{Material and Methods}

\subsection{Isolation of $V$. dahliae from potato plants}

Potato plants generally showing wilt symptoms were collected from 9 locations (Table 1) in Erzurum province between August and September in 2003-2005 growing seasons. Plants were washed with tap water, and then stem sections $1 \mathrm{~cm}$ long were excised from potato plants. The tissue sections were surface disinfected with $0.5 \%$ sodium hypochlorite solution for $1 \mathrm{~min}$, rinsed with sterile distilled water, dried on sterile filter paper and placed on water agar (WA, 2\%) amended with $100 \mathrm{mg} \mathrm{L}^{-1}$ streptomycin sulfate in Petri plates. Plates were incubated at $24{ }^{\circ} \mathrm{C}$ in the dark for 7 days until verticillately branched conidiophores formed around the stem sections. Emerging fungi were subcultured on potato dextrose agar (PDA). Singlespore isolates of $V$. dahliae were obtained, identified as described previously (Hawksworth \& Talboys 1970; Goud et al 2003), and maintained on PDA medium in tubes at $5{ }^{\circ} \mathrm{C}$.

\subsection{Generation and characterization of nit mutants}

Nit mutants of $V$. dahliae were generated on cornmeal agar with $0.02 \%$ glucose amended with $3 \%$ potassium chlorate (CMC) as described previously (Korolev \& Katan 1997). Mycelial discs (5 mm diam.) of $V$. dahliae isolates were removed from the margin of each actively growing colony on PDA and placed on CMC at six separate points in $9 \mathrm{~cm}$ diameter Petri plates. Plates were incubated in the dark at $24{ }^{\circ} \mathrm{C}$ for $2-4$ weeks. Chlorate-resistant sectors were transferred to Czapex-Dox Agar (CDA) plates. Sectors that grew on $\mathrm{CDA}$ as thin expansive colonies with no aerial mycelium were considered nit mutants.

CDA amended with sodium nitrite $\left(0.5 \mathrm{~g} \mathrm{~L}^{-1}\right)$ or hypoxanthine $\left(0.2 \mathrm{~g} \quad \mathrm{~L}^{-1}\right)$ was used for partial phenotyping of the nit mutants (Correll et al 1987). Mutants that grew profusely on sodium nitrite and hypoxanthine were classified as nit 1 , whereas mutants that grew profusely on sodium nitrite but sparsely on hypoxanthine were classified as nit $\mathrm{M}$.

Table 1- Geographical distribution and vegetative compatibility groups (VCGs) of Verticillium dahliae isolates from potato plants during 2003-2005 in Erzurum province Çizelge 1-Erzurum ilinde 2003-2005 yllarında patates bitkilerinden elde edilen Verticillium dahliae izolatlarının coğrafik dağılımı ve vejetatif uyum grupları (VCGs)

\begin{tabular}{|c|c|c|c|c|c|c|c|}
\hline \multirow{2}{*}{ Location } & \multirow{2}{*}{$\begin{array}{c}\text { Plants } \\
\text { sampled }\end{array}$} & \multirow{2}{*}{$\begin{array}{l}\text { No. of } \\
\text { isolates }\end{array}$} & \multicolumn{3}{|c|}{ Number of nit mutants } & \multicolumn{2}{|c|}{ VCGs } \\
\hline & & & nitl & nitM & Total & $V C G 2 B$ & $V C G 4 B$ \\
\hline Asskale & 180 & 19 & 33 & 10 & 43 & 7 & 12 \\
\hline Center & 320 & 13 & 17 & 11 & 28 & 3 & 10 \\
\hline Horasan & 120 & 7 & 10 & 6 & 16 & - & 7 \\
\hline Ilica & 60 & 1 & 2 & 0 & 2 & - & 1 \\
\hline İspir & 40 & 1 & 0 & 1 & 1 & 1 & - \\
\hline Köprüköy & 160 & 16 & 27 & 14 & 41 & 9 & 7 \\
\hline Narman & 120 & 2 & 1 & 2 & 3 & 2 & - \\
\hline Pasinler & 360 & 50 & 79 & 25 & 104 & 12 & 38 \\
\hline Tortum & 100 & 2 & 2 & 0 & 2 & - & 2 \\
\hline Total & 1460 & 111 & 171 & 69 & 240 & 34 & 77 \\
\hline
\end{tabular}

\subsection{Vegetative compatibility grouping}

All nit mutants obtained in this study were paired with nit mutants (nit 1 and nit $\mathrm{M}$ ) of VCG tester isolates of $V$. dahliae. A set of VCG tester isolates [VCG 1 (T9), VCG 2A (PH), VCG 2B (115), VCG 3 (70-21), VCG 4A (BB, P103) and VCG 4B (S-39, MT)] was provided

by Dr. R. C. Rowe (Department of Plant

Tarım Bilimleri Dergisi - Journal of Agricultural Sciences 18 (2012) 110-114 
Pathology, Ohio State University, Ohio Agricultural Research and Development Center, Wooster, Ohio, 44691, USA) and Dr. M. M. Jimenez-Gasco (Department of Plant Pathology, The Pennsylvania State University, University Park, PA 16802, USA). Phenotypically distinct mutants were placed $1.5 \mathrm{~cm}$ apart on CDA in $9 \mathrm{~cm}$ diameter Petri plates and incubated at $24{ }^{\circ} \mathrm{C}$ for $2-4$ weeks. Complementation was evident by the development of prototrophic growth where two mutant colonies met and formed a stable heterokaryon (Bao et al 1998). The degree of complementation was ranked as follows: $(+)=$ dense prototrophic growth, $(+/-)=$ small microsclerotial dots with or without a little aerial mycelium, (-) = prototrophic growth absent or inconspicuous (Korolev et al 2000). Each pairing was repeated at least twice. When mutants of two isolates formed a heterokaryon, their parents were assigned to the same VCG.

\subsection{Pathogenicity of $V$. dahliae isolates on potato}

Pathogenicity of 10 isolates of each VCG, selected at random on the basis of geographical origin, was determined on potato plants (cv. Marfona) by the rootdip method. This cultivar has been grown in Erzurum for a long time. Surface-disinfected potato tubers (1 min in $2 \%$ formaldehyde and rinsed in sterile distilled water) were planted in $15 \mathrm{~cm}$ diameter pots containing a sterile soil mix of topsoil and sand $(1: 1, \mathrm{v} / \mathrm{v})$ in a growth chamber. After 5 weeks, 10 to $20 \mathrm{~cm}$ tall plants were selected for inoculation (Joaquim \& Rowe 1991). The isolates were grown on PDA (9-cm plates) at $24^{\circ} \mathrm{C}$ in the dark for 10 days. Conidia were washed off the agar surface with sterile distilled water, and the inoculum density adjusted to $10^{6}$ conidia $\mathrm{mL}^{-1}$ with a hemacytometer and sterile distilled water (Strausbaugh 1993). Potato plants were uprooted from soil mix, rinsed in sterile distilled water, and dipped in a conidial suspension for $30 \mathrm{~min}$. Inoculated plants were transplanted into $15 \mathrm{~cm}$-diam pots containing a sterile soil mix. Control plants were dipped in sterile distilled water before transplanting. Plants were grown in a growth chamber at $24{ }^{\circ} \mathrm{C}$ under a $16 \mathrm{~h}$ photoperiod. A completely randomized design with four replicate pots per isolate was used. Sixty five days after inoculation, disease severity was rated on a scale 0 to $3(0=$ no symptoms, $1=$ vascular discoloration without apparent leaf symptoms, $2=$ vascular discoloration with leaf-wilt symptoms, $3=$ dead plant) as described previously (Bao et al 1998). After disease evaluations, small sections from all above-ground parts (stem, petiole and leaf) of each plant were surface disinfected and placed on WA to determine the presence of $V$. dahliae. Statistical analysis was performed by SAS Software (SAS Institute Inc., Cary, NC, USA). The General Linear
Models procedure was used to test effects at the 0.05 level of probability and means were compared by $t$ test.

\section{Results and Discussion}

\subsection{Isolates of $V$. dahliae from potato plants}

Stem samples were collected from potato fields in Erzurum province. The number of potato stems excised from plants onto culture media in the laboratory totaled 1460 during the 3 years, and $V$. dahliae was isolated from $7.6 \%$ of the stems examined. Totally, 111 isolates of $V$. dahliae were obtained from potato stems from 9 locations (Table 1). Most of these isolates were collected from Pasinler.

\subsection{Generation and characterization of nit mutants}

In total, 240 nit mutants were obtained from 111 isolates of $V$. dahliae, ranging from 1 to 7 mutants per isolate. Nit mutants were identified based on their phenotype; 171 mutants were classified as nit 1 and the remainder as nit $\mathrm{M}$ (Table 1). Similar frequencies of nit 1 and nit $\mathrm{M}$ classes were found for $V$. dahliae from various hosts including potato (Bao et al 1998; Zeise \& Tiedemann Von 2001; Demirci \& Genc 2009). In this study, twelve isolates produced both types of mutants, 68 the nit 1 type mutant and 31 the nit $\mathrm{M}$ type mutant only (data not shown). No nit3 mutants were recovered.

\subsection{Vegetative compatibility grouping}

The genetic diversity among one hundred eleven $V$. dahliae isolates was determined. After complementation with the tester isolates of known VCGs, 34 isolates were assigned to VCG 2B, and 77 to VCG 4B (Table 1). Isolates assigned to VCG 2 showed strong complementation only with tester isolates of VCG 2B. Cross-reactions occurred between isolates VCG 4 from potato plants and tester isolates of VCG 4 (subgroups A and B), VCG 4 isolates showed strong complementation $(+)$ with the tester isolates of VCG $4 \mathrm{~B}$, but all were also weakly compatible (+/-) with the tester isolates of VCG 4A. Unfortunately a mistake was made on the determination of the VCG of a number of isolates of $V$. dahliae from potato plants (Dane 2007). In this thesis, isolates of $V$. dahliae were typed as VCG 4A due to problems with some tester isolates. After we were aware of this problem, new VCG tester isolates [VCG 4A (BB, P103) and VCG 4B (S-39, MT)] of $V$. dahliae were provided by Dr. M. M. Jimenez-Gasco. The vegetative compatibility of isolates previously typed as VCG 4A was re-evaluated. All nit mutants of VCG 4 obtained in this study were paired with nit mutants of new tester isolates of VCG 4A and 4B. Eventually, all VCG 4 isolates from potato plants in Erzurum were re-classified as VCG 4B in this article.

Both VCG 2B and VCG 4B isolates were identified from Center, Aşkale, Köprüköy and Pasinler. Only VCG 2B isolates were identified from İspir and 
Narman, and only VCG 4B isolates were identified from Horasan, Ilica and Tortum. Both VCG 2B (Zeise \& Tiedemann Von 2002) and VCG 4B (Joaquim \& Rowe 1991; Strausbaugh 1993; Korolev et al 2000; Tsror et al 2001; Zeise \& Tiedemann Von 2002) isolates have been reported before on potato. In a study from Erzurum, $V$. dahliae isolates from some of the common weeds in potato fields also were assigned to VCG 2B and VCG 4B (Demirci \& Genc 2009; 2011). The results suggest that the population of $V$. dahliae isolates from potato plants and weeds in potato fields is the same. This is the first study of vegetative compatibility of $V$. dahliae isolates from potato plants in Turkey.

3.4. Pathogenicity of $V$. dahliae isolates on potato The pathogenicity of twenty isolates representing VCG 2B and VCG 4B was determined on potato plants by the root-dip method. Potato plants all exhibited typical Verticillium wilt symptoms in response to inoculation with the tested $V$. dahliae isolates. Disease symptoms were visible 5-6 weeks after inoculation and developed over time from chlorosis to necrosis and wilting. When

stem sections of these plants were dissected, they all showed vascular discoloration. Based on the results of pathogenicity tests, all isolates were pathogenic on potato at various levels of aggressiveness (Table 2). Disease severity ranged from 1.5 to 2.8 for VCG $2 \mathrm{~B}$ isolates, and from 2.0 to 2.5 for $\mathrm{VCG} 4 \mathrm{~B}$ isolates. No significant differences $\left(F_{4,80}=0.66, \quad P=0.42\right)$ were observed among the tested VCG $2 \mathrm{~B}$ and $4 \mathrm{~B}$ for disease severity. Control plants showed no disease symptoms. $V$. dahliae was recovered from all the inoculated plants but not from control plants.

The present study showed that most isolates of VCG 2B and VCG 4B from potato plants were highly aggressive on potato cv. "Marfona", and there was no difference between the isolates for disease severity.

Disease severity of potato plants infected with $V$. dahliae isolates from weed species in Erzurum ranged from 1.6 to 2.3 for both VCG $2 \mathrm{~B}$ and VCG 4B isolates (Demirci \& Genc, 2009 \& 2011). However, symptom severity was significantly higher in potato plantlets inoculated with VCG 4B than VCG $2 \mathrm{~A}$ and VCG $2 \mathrm{~B}$ (Tsror et al 2001).

Table 2- Pathogenicity of Verticillium dahliae isolates on potato cv. Marfona Çizelge 2-Marfona patates çeşidinde Verticillium dahliae izolatlarının patojenitesi

\begin{tabular}{|c|c|c|c|c|c|c|}
\hline \multirow{2}{*}{$V C G s^{(a)}$} & \multirow{2}{*}{ Isolates } & \multirow{2}{*}{ Location } & \multirow{2}{*}{ Disease severity $^{(b)}$} & \multicolumn{3}{|c|}{ Plant colonization $^{(c)}$} \\
\hline & & & & Stem & Petiole & Leaf \\
\hline \multirow{10}{*}{ VCG 2B } & OA04-1-8 & Aşkale & 2.3 & $4 / 4$ & $3 / 4$ & $0 / 4$ \\
\hline & OA04-2-2 & Aşkale & 2.5 & $4 / 4$ & $3 / 4$ & $1 / 4$ \\
\hline & OA05-1-3 & Aşkale & 1.5 & $4 / 4$ & $0 / 4$ & $0 / 4$ \\
\hline & 4.Kuyu05-1 & Center & 2.0 & $4 / 4$ & $3 / 4$ & $0 / 4$ \\
\hline & Bi1-2 & İspir & 2.3 & $4 / 4$ & $4 / 4$ & $0 / 4$ \\
\hline & KöDç05-2-4 & Köprüköy & 2.3 & $4 / 4$ & $1 / 4$ & $0 / 4$ \\
\hline & NM05-4-2 & Narman & 2.3 & $4 / 4$ & $2 / 4$ & $0 / 4$ \\
\hline & PM04-1 & Pasinler & 2.0 & $4 / 4$ & $4 / 4$ & $0 / 4$ \\
\hline & EP04-4 & Pasinler & 2.0 & $4 / 4$ & $2 / 4$ & $0 / 4$ \\
\hline & PTi04-2 & Pasinler & 2.8 & $4 / 4$ & $4 / 4$ & $1 / 4$ \\
\hline \multirow{10}{*}{ VCG 4B } & OA04-2-3 & Aşkale & 2.3 & $4 / 4$ & $3 / 4$ & $0 / 4$ \\
\hline & OA05-4-2 & Aşkale & 2.5 & $4 / 4$ & $4 / 4$ & $1 / 4$ \\
\hline & Tu04-2 & Center & 2.5 & $4 / 4$ & $4 / 4$ & $1 / 4$ \\
\hline & HÇ05-1 & Horasan & 2.5 & $4 / 4$ & $4 / 4$ & $2 / 4$ \\
\hline & I05-1-1 & Ilıca & 2.5 & $4 / 4$ & $4 / 4$ & $0 / 4$ \\
\hline & Кӧ04-2 & Köprüköy & 2.0 & $4 / 4$ & $3 / 4$ & $0 / 4$ \\
\hline & AP05-2-2 & Pasinler & 2.0 & $4 / 4$ & $3 / 4$ & $1 / 4$ \\
\hline & PM04-7 & Pasinler & 2.5 & $4 / 4$ & $4 / 4$ & $2 / 4$ \\
\hline & PM04-8 & Pasinler & 2.0 & $4 / 4$ & $3 / 4$ & $0 / 4$ \\
\hline & TA05-2 & Tortum & 2.0 & $4 / 4$ & $3 / 4$ & $0 / 4$ \\
\hline
\end{tabular}

\footnotetext{
(a) Vegetative compatibility groups of $V$. dahliae isolates.
}

(b) Disease severity was on a scale of 0 to $3 ; 0=$ no symptoms, $1=$ vascular discoloration without apparent leaf symptoms, $2=$ vascular discoloration with leaf-wilt symptoms, $3=$ dead plant (Bao et al 1998).

(c) Number of plants colonized by $V$. dahliae / total number of examined plants.

In other researches, VCG 4A isolates were more virulent on potato than VCGs 2 and 4B (Joaquim \&
Rowe 1991) or VCGs 4B and 4A/B isolates (Strausbaugh 1993).

Rotation is one of the major components of 
Verticillium wilt management. However, many field crops, vegetables and weeds are susceptible to the pathogens causing this disease. In addition, microsclerotia produced by $V$. dahliae in the dying tissues of the infected plant can survive in the soil for many years (Pegg \& Brady 2002). Moreover, one study has reported that formation of microsclerotia in senescent tissues of infected weeds could be an important factor in the failure of rotation programs to control V. dahliae effectively (Johnson et al 1980). Another study showed that some of the common weeds in potato fields can act as potential hosts of $V$. dahliae and potentially play important role in the survival of this pathogen (Demirci \& Genc 2009). Therefore, weed control in potato fields is also very important.

\section{Conclusion}

The results of this study show that $V$. dahliae isolates from potato in Erzurum were classified as VCG 2B and VCG 4B. There are no statistically significant differences between VCG $2 \mathrm{~B}$ and $4 \mathrm{~B}$ isolates on disease severity.

\section{Acknowledgements}

The authors would like to thanks the Atatürk University Scientific Research Projects Unit for financial support.

\section{References}

Bao J R, Katan J, Shabi E \& Katan T (1998). Vegetativecompatibility groups in Verticillium dahliae from Israel. European Journal of Plant Pathology 104: 263-269

Correll J C, Klittich C J R \& Leslie J F (1987). Nitrate nonutilizing mutants of Fusarium oxysporum and their use in vegetative compatibility tests. Phytopathology 77 : $1640-1646$

Dane E (2007). Erzurum ilinde patates (Solanum tuberosum L.) bitkisinden izole edilen Verticillium dahliae Kleb.'nın vejetatif uyum grupları ve patojeniteleri. Doktora tezi, Atatürk Üniversitesi Fen Bilimleri Enstitüsü (Basılmamış), Erzurum

Demirci E \& Genc T (2009). Vegetative compatibility groups of Verticillium dahliae isolates from weeds in potato fields. Journal of Plant Pathology 91: 671-676

Demirci E \& Genc T (2011). Erratum to: Vegetative compatibility groups of Verticillium dahliae isolates from weeds in potato fields. Journal of Plant Pathology 93: 757.

Goud J K, Termoshuizen A J \& Gams W (2003). Morphology of Verticillium dahliae and V. tricorpus on semi-selective media used for the detection of V.dahliae in soil. Mycological Research 107: 822-830

Hawksworth D L \& Talboys P W (1970). Verticillium dahliae. C.M.I. Descriptions of Pathogenic Fungi and Bacteria, Section 26, Sheat No 256, Commonwealth Mycological Institute, Kew, England

Joaquim T R \& Rowe R C (1990). Reassessment of vegetative compatibility relationships among strains of Verticillium dahliae using nitrate-nonutilizing mutants. Phytopathology 80: 1160-1166

Joaquim T R \& Rowe R C (1991). Vegetative compatibility and virulence of strains of Verticillium dahliae from soil and potato plants. Phytopathology 81: 552-558

Johnson W M, Johnson E K \& Brinkerhoff L A (1980). Symptomatology and formation of microsclerotia in weeds inoculated with Verticillium dahliae from cotton. Phytopathology 70: 31-35

Korolev N \& Katan T (1997). Improved medium for selecting nitrate-nonutilizing (nit) mutants of Verticillium dahliae. Phytopathology 87: 1067-1070

Korolev N, Katan J \& Katan T (2000). Vegetative compatibility groups of Verticillium dahliae in Israel: Their distribution and association with pathogenicity. Phytopathology 90: 529-536

Ligoxigakis E K, Vakalounakis D J \& Thanassoulopoulos C C (2002). Weed hosts of Verticillium dahliae in Crete: susceptibility, symptomatology and significance. Phytoparasitica 30: 511-518

Pegg G F \& Brady B L (2002). Verticillium wilts. CABI Publishing, Wallingford, UK.

Rich A E (1986). Verticillium wilt. In: Hooker W C (ed) Compendium of Potato Diseases, The American Phytopathological Society, USA, pp 62-63

Strausbaugh C A (1993). Assessment of vegetative compatibility and virulence of Verticillium dahliae isolates from Idaho potatoes and tester strains. Phytopathology 83: 1253-1258

Tsror (Lahkim) L, Hazanovsky M, Mordechi-Lebiush S \& Sivan S (2001). Aggressiveness of Verticillium dahliae isolates from different vegetative compatibility groups to potato and tomato. Plant Pathology 50: 477-482

Zeise K \& Tiedemann Von A (2001). Morphological and physiological differentiation among vegetative compatibility groups of Verticillium dahliae in relation to Verticillium longisporum. Journal of Phytopathology 149: $469-475$

Zeise K \& Tiedemann Von A (2002). Host specialization among vegetative compatibility groups of Verticillium dahliae in relation to Verticillium longisporum. Journal of Phytopathology 150: 112-119 